\begin{tabular}{|c|c|}
\hline & $\begin{array}{l}\text { International Journal of Trend in Scientific } \\
\text { Research and Development (IJTSRD) }\end{array}$ \\
\hline 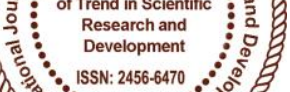 & International Open Access Journal \\
\hline 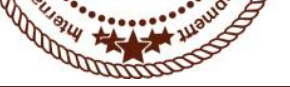 & ISSN No: $2456-6470 \mid$ www.ijtsrd.com | Volume - 2 | Issue -5 \\
\hline
\end{tabular}

\title{
Phytochemical Screening and GC-MS Analysis of Cardiospermum halicacabum L. Leaf Extract
}

\author{
S. Nathiya ${ }^{1}$, B. Senthil Kumar ${ }^{2}$, K. Devi ${ }^{3}$ \\ ${ }^{1}$ Students, ${ }^{2,3}$ Professor and Head, \\ $1,2,3$ Department of Zoology, \\ ${ }^{1,2}$ D. K. M. College for Women, Vellore, Tamil Nadu, India \\ ${ }^{3}$ Thiruvalluvar University, Vellore, Tamil Nadu, India
}

\section{ABSTRACT}

Plants have more vital sources of natural products and involving in the human health care system since the human civilization starting. Cardiospermum halicacabum L. is an Indian folklore medicinal plant and its family Sapindaceae. They have more potential in many biological activities with the presence of bioactive compounds. The aim of the present study was carried out by phytochemical screening and the GC-MS analysis was proven leaf extract of Cardiospermum halicacabum L. was having important secondary metabolities are Alkaloids, Amino acids, Cardiac Glycosides, Flavonoids, Steriods, Terpenoids and Phenols are present in phytochemical screening and the 12 compounds are identified in GC-MS studies [Tricyclo[5.4.3.0(1,8)]tetradecan-6-one, 4-ethenyl (33.50) and the lowest peak of compound is Aziridine, 2-(1,1-dimethylethyl)-3-methyl (0.10)] and involving many biological activity, they are anti-inflammatory, antineoplastic agent, Antigonistic, Antifungal, Antimicrobial, anthelmintic, Atitumor, protect cardiovascular diseases, Growth regulating activity, Anti-ACHE in the treatment of Myasthenia Gravis, Antiarrhymthmic properties, Antihepatotoxic. Hence this study is revealed the bioactive compounds, and its molecular formula, weight, and biological activity. This study is May helpful for screening to develop new drugs with traditionaly in pharmaco service system.

Keywords: Anti-inflammatory, Antineoplastic agent, Antigonistic, Antifungal, Antimicrobial, Anthelmintic, Antitumor

\section{INTRODUCTION}

Medicinal Plants and its products have been historically of indigenous use in India as well as other countries. India has a rich repository of medicinal plants and predominantly used Phytotherapy has a very long tradition. They have played an important role since the human civilization starting. According to WHO (World Health Organization) estimated that $80 \%$ of people used in this herbal medicine for some aspect of their primary health care needs. This traditional use of medicinal plants having a huge amount of bioactive compounds, these compounds are involving to treat and cure various ailments in the related of different diseases. These herbal medicines are free from side effect and safe comparatively synthetic drugs.

Cardiospermum halicacabum L. is family Sapindaceae commonly known as Mudakathan in Tamil, it is us folk medicine of India. The whole plant material is used to cure many diseases, including rheumatism, nervous diseases, stiffness of the limbs of snake bites; asthma patients take fresh leaf juice to orally and reduce obesity (Dinithi C. Perris et al., 2015). The plant possesses various medicinal properties such antioxidant, anti-inflammatory, Vasodepresent activity (Sagadevan P et al., 2014).

\section{Materials and Methods}

\section{Collection of Plant material}

Cardiospermum halicacabum $L$. leaves were collected from around Vellore District. The leaves were removed dust, shade dried, blends to form a fine powder and stored in airtight bottles 


\section{Extract preparation}

$25 \mathrm{~g}$ of plant material was soxholated with double distilled water at $100^{\circ} \mathrm{C}$ for $12 \times 3 \mathrm{hrs}$. The soxholated material was filtered and the filtrate was evaporated using as oven at $50-60{ }^{0} \mathrm{C}$. Appropriate weights of the residue were prepared in distilled water to acquire the various concentrations used for this analysis (Lohiya et al., 1994).

\section{Phytochemical analysis}

The extract of Cardiospermum halicacabum L.tested for the bioactive compounds by using the following methods.

\section{Test for Saponins}

$5 \mathrm{ml}$ of sample was shaken vigorously with $5 \mathrm{ml}$ of distilled water in a test tube and warmed. The formation of stable foam was taken as an indication of the presence of saponins.

\section{Test for Phlorotannins}

About $2 \mathrm{ml}$ of sample was added to $2 \mathrm{ml}$ of $1 \% \mathrm{HCl}$ and the mixture was boiled. Deposition of a red precipitate was taken as an evidence for the presence of phlorotannins.

\section{Test for Glycoside; Liebermanns test:}

$2 \mathrm{ml}$ of the sample was dissolved in $2 \mathrm{ml}$ of chloroform and then $2 \mathrm{ml}$ of acetic acid was added in it. The solution was cooled well in ice. Sulphuric acid was then added carefully. A color change from violet to blue to green indicates the presence of a steroid nucleus (that is, a glycone portion of glycoside).

\section{Test for Alkaloids}

$3 \mathrm{ml}$ sample was stirred with $3 \mathrm{ml}$ of $1 \% \mathrm{HCl}$ on the steam bath. Mayer and Wagner's reagent were then added to the mixture. Turbidity of the resulting precipitate was taken as an evidence for the presence of alkaloid

\section{Test for Flavanoids}

To $1 \mathrm{ml}$ of aqueous extract, $1 \mathrm{ml}$ of $10 \%$ lead acetate solution was added. The formation of a yellow precipitate was taken as a positive test for flavonoid. From the analysis of the plant the major phytochemical constituents which showed the positive result are being glycosides, alkaloids, and flavonoids.

\section{Test for Tannins}

About $2 \mathrm{ml}$ of the sample was stirred with $2 \mathrm{ml}$ of distilled water and few drops $1 \mathrm{FeCl} 3$ solution was added. Formation of green precipitate was an indication of presence of tannins.

\section{Test for Terpenoids}

$2 \mathrm{ml}$ of the sample was dissolved in $2 \mathrm{ml}$ of chloroform and evaporated to dryness. $2 \mathrm{ml}$ of concentrated sulphuric acid was then added and heated for about $2 \mathrm{~min}$. Development of a grayish colour indicates the presence of terpenoids

\section{Tests for steroids}

A red colour produced in the lower chloroform layer when $2 \mathrm{ml}$ of sample was dissolved in $2 \mathrm{ml}$ of chloroform and $2 \mathrm{ml}$ concentrated sulphuric acid is added in it indicates the presence of steroids.

\section{GC-MS Analysis}

The GC-MS analysis of leaf extract Cardiospermum halicacabum was performed using a Shimdzu GC2010 Plus gas chromatograph was equipped with a straight deactivated $2 \mathrm{~mm}$ direct injector liner and a $15 \mathrm{~m}$ Alltech EC-5 column (250 $\mu$ I.D., $0.25 \mu$ film thickness). A split injection was used for sample introduction and the split ratio was set of 10:1. The oven temperature program was programmed to start at $35^{\circ} \mathrm{C}$, hold for 2 minutes, then ramp at $20^{\circ} \mathrm{C}$ per minute to $450^{\circ} \mathrm{C}$ and hold for 5 minutes. The helium carrier gas was set to $2 \mathrm{ml} /$ minute flow rate (constant flow mode). A Direct connection with capillary column metal quadupole mass filter pre-rod mass spectrometer operating in electron ionization (EI) mode with software GC-MS solution ver. 2.6 was used for all analyses. Low-resolution mass spectra were acquired at a resolving power of $1000(20 \%$ height definition) and scanning from $\mathrm{m} / \mathrm{z} 25$ to $\mathrm{m} / \mathrm{z}$ 1000 at 0.3 seconds per scan with a 0.2 Second interscan delay. High resolution mass spectra were acquired at a resolving power of 5000 (20\% height definition) and scanning the magnet from $\mathrm{m} / \mathrm{z} 65$ to $\mathrm{m} / \mathrm{z} 1000$ at 1 second per scan.

Identification of the components of the compound was matching their recorded spectra with the data bank mass spectra of NIST library V 11 provided by the instrument software and GC-MS metabolomics.

The Database was used for the similarity search in retention index.

\section{RESULT}

The Phytochemical screening of Cardiospermum halicacabum L. leaf was analyzed by standard 
methods and identified the bioactive compounds they are flavonoids, glycosides, tannins, terpenoids, phenol, steroids, alkaloids, saponins and carbohydrates are found in the leaf extract cardiospermum halicacabum L. and the finding compounds are present in the Table 1.

Table1. Phytochemical Constituents analysis of Cardiospermum halicacabum L.

\begin{tabular}{|l|c|c|}
\hline $\begin{array}{c}\text { S. } \\
\text { No }\end{array}$ & Name of the Test & $\begin{array}{c}\text { Phytochemical analysis of } \\
\text { Cardiospermum halicacabum } \mathrm{L} .\end{array}$ \\
\hline 1. & Alkaloids & + \\
\hline 2. & Amino acids & + \\
\hline 3. & Anthraquinones & - \\
\hline 4. & Carbohydrates & + \\
\hline 5. & Cardiac Glycosides & - \\
\hline 6. & Coumorins & + \\
\hline 7. & Flavonoids & - \\
\hline 8. & Proteins & - \\
\hline 9. & Saponins & + \\
\hline 10. & Steriods & - \\
\hline 11. & Tannins & + \\
\hline 12. & Terpenoids & + \\
\hline 13. & Phenols & \\
\hline
\end{tabular}

The Bioactive compounds present in the leaf extract compounds are identified the highest of the peaks of of Cardiospermum halicacabum L. were identified by using GC-MS analysis shows active principles with compound is Tricyclo[5.4.3.0(1,8)]tetradecan-6-one, 4-ethenyl (33.50) and the lowest peak of compound is their retention time (RT), Molecular formula, Aziridine, 2-(1,1-dimethylethyl)-3-methyl (0.10). Molecular Weight (MW) and concentration (peak area These bioactive components are present in the leaf $\%)$ are presented in Table 2 . The 15 prevailing extract of Cardiospermum halicacabum L.

Table2. Phytocomponents identified in the leaf extract of Cardiospermum halicacabum L. by GC-MS analysis.

\begin{tabular}{|l|c|c|c|c|c|}
\hline $\begin{array}{c}\text { S. } \\
\text { No. }\end{array}$ & RT & $\begin{array}{c}\text { Peak } \\
\text { Value }\end{array}$ & $\begin{array}{c}\text { Compound Name } \\
\text { Weight }\end{array}$ & $\begin{array}{c}\text { Molecular } \\
\text { Formula }\end{array}$ \\
\hline 1. & 5.48 & 0.10 & Aziridine, 2-(1,1-dimethylethyl)-3-methyl & 141 & C9H19N \\
\hline 2. & 6.45 & 0.01 & DBenzoic acid, 2-(1-oxopropyl)-, methyl ester & 192 & C11H12O3 \\
\hline 3. & 7.33 & 0.03 & 3-(1,4-Dioxa-8-aza-spiro[4.5]dec-8-ylmethyl) & 336 & C14H18BrMgNO2 \\
\hline 4. & 19.91 & 0.12 & Pyridostigmine Bromide $\$ \$$ & 261 & C9H13BrN2O2 \\
\hline 5. & 25.92 & 0.01 & Bicyclo(3.3.1)nonan-9-one, 2-(1-pyrrolidinyl) & 2017 & C13H21NO \\
\hline 6. & 29.10 & 0.01 & 7-methoxy-5,11, 12-trihydroxy coumestan & 314 & C16H10O7 \\
\hline 7. & 35.73 & 0.02 & 3-Hydroxy-7,8-dihydro-.beta.-ionol & 208 & C13H20O2 \\
\hline 8. & 37.66 & 0.01 & 3,3-Dimethyl-1-(2-carboxyphenyl)triazene & 193 & C9H11N3O2 \\
\hline 9. & 40.55 & 0.01 & Luteolin 2-hydroxy methane & 286 & C15H10O6 \\
\hline 10. & 45.13 & 15.21 & Di-n-decylsulfone & 346 & C20H42O2S \\
\hline 11. & 45.50 & 31.78 & Apigenin Sulfate & 364 & C15H8O9S \\
\hline 12. & 45.95 & 33.50 & Tricyclo[5.4.3.0(1,8)]tetradecan-6-one, 4 ethenyl & 378 & C22H34O5 \\
\hline
\end{tabular}




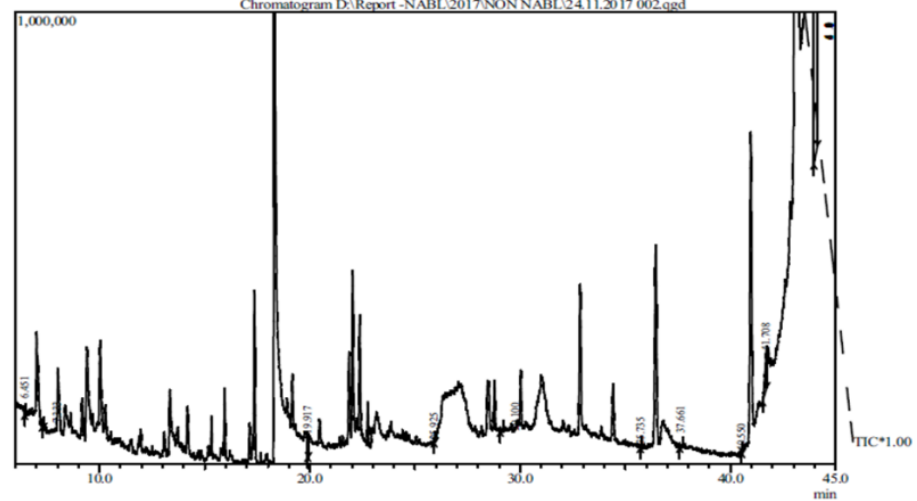

The highest Peak value of compound Apigenin Sulfate 45.50 Atitumor and protect cardiovascular diseases, Di-n-decylsulfone 15.21 Antigonistic, Antifungal, Antimicrobial, Antihelmintic Luteolin 2hydroxy methane 0.01 Antioxidant, antiinflammatory, antineoplastic agent.

Table.3 Represent the Biological activity of Identified in the leaf extract of Cardiospermum halicacabum L.

\begin{tabular}{|l|c|c|}
\hline $\begin{array}{c}\text { S. } \\
\text { No. }\end{array}$ & Compound Name & $\begin{array}{c}\text { Biological } \\
\text { activity } \\
\text { Anti Neo plastic } \\
\text { agent }\end{array}$ \\
\hline 1. & $\begin{array}{c}\text { 3,3-Dimethyl-1-(2- } \\
\text { carboxyphenyl)triazene }\end{array}$ & $\begin{array}{c}\text { Antioxidant, anti- } \\
\text { inflammatory, } \\
\text { antineoplastic } \\
\text { agent }\end{array}$ \\
\hline 3. & $\begin{array}{c}\text { Luteolin 2-hydroxy } \\
\text { methane }\end{array}$ \\
\hline 4. & Di-n-decylsulfone & $\begin{array}{c}\text { Antigonistic, } \\
\text { Antifungal, } \\
\text { Antimicrobial, } \\
\text { Antihelmintic }\end{array}$ \\
\hline 5. & $\begin{array}{c}\text { A-(1,4-Dioxa-8-aza- } \\
\text { spiro[4.5]dec-8-ylmethyl) }\end{array}$ & $\begin{array}{c}\text { Antitumor, protect } \\
\text { cardiovascular } \\
\text { diseases, }\end{array}$ \\
\hline 6. & $\begin{array}{c}\text { Prowth regulating } \\
\text { activity }\end{array}$ \\
\hline 7. & $\begin{array}{c}\text { Bicyclo(3.3.1)nonan-9- } \\
\text { one, 2-(1-pyrrolidinyl) }\end{array}$ & $\begin{array}{c}\text { Anti-ACHE in the } \\
\text { treatment of } \\
\text { Ayasthenia } \\
\text { gravis. }\end{array}$ \\
\hline 8. & $\begin{array}{c}\text { 7-methoxy-5, 11, 12- } \\
\text { trihydroperties }\end{array}$ \\
\hline
\end{tabular}

\section{DISCUSSION}

In the present study revealed the secondary metabolites of alkaloids, Amino acids, Cardiac Glycosides, Flavonoids, Steriods, Terpenoids and Phenols are present in the leaf extract of Cardiospermum halicacabum L. These effective compounds are medically important and more potential to responsible for food industry and pharmacological activities. The GC-MS analysis is a precious tool for identification of phytocompounds. In the present study identified to 12 bio active compounds in the leaf extract of Cardiospermum halicacabum $\mathrm{L}$. and these bio active compounds are responsible in the many biological, anti-inflammatory, antineoplastic agent, Antigonistic, Antifungal, Antimicrobial, anthelmintic, Atitumor, protect cardiovascular diseases, Growth regulating activity, Anti-ACHE in the treatment of Myasthenia Gravis, Antiarrhymthmic properties, Antihepatotoxic. In this study of phytochemical screening and GC-MS analysis properties, they are antitumor activity, Antioxidant is proving this plant have more bioactive compounds and posses medicinal property.

\section{CONCLUSION}

The phytochemical screening and GC-MS analysis of leaf extract of Cardiospermium halicacabum L. constitute various bioactive compounds. These components have many therapeutic properties also involved in many biological activity and various ailments are cure traditionally in medicinal field. Hence this investigation give the information of leaf extract of Cardiospermium halicacabum L. is pharmacology more potential for using the method of phytochemical screening and GC-Ms analysis are proven.

\section{ACKNOWLEDGEMENT}

We would like to thank My Guide and Supervisor Dr. K. Devi Associate professor PG and Research Department of Zoology, D. K. M. College for Women Vellore -1 for guiding and supporting me.

\section{]REFERENCE}

1. Aneesh TP. Mohamed Hisham, Sonal Sekhar M, Manjusree Madhu Deepa TV. International Market Scenario of Traditional Indian Herbal Drugs. Int. J. Green Pharm. 2009; 3 suppl 3: 184190.

2. Home page on the internet, World Health Organization, available from url http://www.Who.int/medicines/areas/traditional/de finitions/en.

3. Sagadevan P, S. N. Suresh, S. Rathish kumar and Revathy Rajan A. R., Studies on phytochemical composition, antibacterial and antioxidant potential of methanolic stem extract of 
Cardiospermum halicacabum L. (Sapindaceae)., International Journal of Biosciences and Nanosciences Volume 1 (1), 2014, PP. 12-18.

4. L. Dinithi C. Perris, M. A. T. Dhanuska and T. A. H. D. G. Jayathilake, 2015 Evaluation of Aqueous of Leaf Extract of Cardiospermum halicacabum (L.) on Fertility of Male Rats, BioMed Research International.

5. Deshmukh, O. S., 2015 GC-MS Analysis of Root Acetone Extracts of Spatholobus Purpureus - A High Ethno - Veterinary Medicinal Value plant, International Journal of Current Research, Vol. 7, Issue, 11, PP.23039-23042, November.

6. Xiang Zhou, Feng Wang, Ruijun Zhou, Xiuming Song, Meilien Xie, Apigenin: 2017. A current review on its beneficial biological activities, WILEY Journal of Food Biochemistry, DOI: 10.1111/jfbc. 12376 .

7. A. Sh. Sharifkanov, S. K. Alimzhanova, Zh. A. Abilov, and A. A. Bektibaeva, 2001 Synthesis, Structure and Growth Regulating activity of 1-(6,9 - Dimethyl-1, 4-dioxa-8-azaspiro[4,5]dec-8ylmethyl)-1H-pyridin-2-one., Russian journal of Applied chemistry, Vol.74, No. 2, 2001, PP. 277279. Translated from Zhurnal Prikladoni Khimi, Vol. 74, No. 2, 2001. PP. 272-274.
9. Karuppasamy Balamurugan, Antony Nishanthini, Veerababu Ramasamy Mohan. 2012 GC-MS analysis of polycarpaea corymbosa (L.) Lam whole plant, Asian Pasific Journal of Tropical Biomedicine

10. Muthulakshmi A, Joshibhi Margret R, Mohan V R. GC-MS analysis of bioactive components of Feronia elephantum correa (Rutacceae) App. Pharmac. Sci. 2012 2:69-74.

11. A. Malar Retna and P. Ethalsha, Phytochemical Tests, Antioxidant Potential and TLC Analysis of Ipomoea Pes Caprae and Catharanthus Roseus, International Journal of Natural Products Research, 2014; 4(2): 58-64.

12. Tiana Fitrilia, Maria Bintang, Mega Safithri, Phytochemical Screening and antioxidant activity of clove mistletoe leaf extracts (Dendrophthoe Pentandra (L. )Miq)., IOSR Journal of Pharmacy Volume 5. Issure 8 August 2015, PP. 13-18.

13. R. Hemalatha P. Nivetha, C. Mohanapriya, G. Sharmila, C. Muthukumaran, M. Gopinath, Phytochemical Composition, GC-MS analysis, in vitro antioxidant and antibacterial potential of clove flower bud (Eugenia caryophyllus) methanolic extract, J Food Sci Technol Feb 2016., 53(2): 1189-1198.

8. Robert E. Smith, Medicinal Chemistry- Fusion of Traditional and Western Medicine. 